\title{
Improving Social Responsibility in RMG Industries Through a New Governance Approach in Laws
}

\author{
Mia Mahmudur Rahim ${ }^{1}$
}

Received: 27 May 2014/Accepted: 16 March 2016/Published online: 30 March 2016

(C) Springer Science+Business Media Dordrecht 2016

\begin{abstract}
Developing countries need to reform legislation to ensure the global supply firms in ready-made garment (RMG) industry is adequately addressing obligations of social responsibility. Literature typically focuses on strategies for raising responsible standards in global buying firms within the RMG industry, but fails to focus on implementing strategies for suppliers in developing countries. This article addresses this gap by specifically focusing on the RMG industry in Bangladesh, the home of the third largest RMG supplier in the world. It concentrates on analysing how and to what extent the law can assist in developing social responsibility performance of the RMG manufacturing firms in developing countries. It ultimately concludes that a new governance approach in laws can effectively increase the social responsibility practice standards of an industry where global buying firms are profitdriven and governmental agencies are either inadequate or corrupt.
\end{abstract}

Keywords Corporate social responsibility - New governance $\cdot$ Ready-made garments industry $\cdot$ Global buyers $\cdot$ Bangladesh $\cdot$ Global supply chain

\section{Introduction}

The ready-made garments (RMG) industry in Bangladesh experienced the most devastating incident in its history on April 24, 2013. Rana Plaza, an eight-storey factory building

Mia Mahmudur Rahim

miamahmud@hotmail.com

1 School of Law, University of South Australia, Adelaide, Australia where more than four thousand people were working, collapsed and killed 1134 RMG workers (Claeson 2015; Fitch et al. 2015; Muhammad 2014). This cast a spotlight on the poor working conditions in RMG supply firms where millions of workers make garments for consumers worldwide.

Intense publicity, both within Bangladesh and overseas, about this incident has been greater and more widespread than for any other previous incident in the RMG industry worldwide. The building, Rana Plaza, contained a bank, shops and five garment factories ${ }^{1}$ that produced apparel for large Western-based brands like Benetton, Walmart and Primark (Reinecke and Donaghey 2015a; Manik et al. 2013; Passariello and Banjo 2013). Sadly, if these brands had not been affected by the tragedy, the collapse might not have even made international news. However, because of this connection, the disaster has become fodder for the perennial debate over globalization (The Economist 2013; Lund-Thomsen and Lindgreen 2014; Nolan 2014; Perry et al. 2015). Many North American and European humanrights groups and labour activists claim that the Westernbased firms who source garments from overseas should be held responsible for this disaster (Balch 2013; Burke 2014; Carmody 2013; Kinley and Navidi 2013; Muhammad 2014; Taplin 2014; Viedrman 2014). Nonetheless, in Bangladesh, thousands of garment workers took to the streets and were met by police spraying rubber bullets and teargas. These Bangladeshi protesters were not directing their outrage at the Western-based brands or cost-conscious consumers, but at their own failed network of governance and RMG owners' attitudes towards workers' wellbeing (Bhagwati 2014; Gomes 2013; Hasan 2013; Kanzer 2013; Nasrullah and Rahim 2014; Than 2013).

\footnotetext{
1 These five garments factories were Ether Tex, New Wave Bottoms, the New Wave Style, Fantom Apparels, Fantom Tex.
} 
The garments industry may be global, but many argue that the blame for this disaster should primarily be local, apportioned to the local governance failure, corruption and ineptitude that allowed the Rana Plaza to be illegally built and occupied in the first place (Akhter 2014; Gomes 2013; Reinecke and Donaghey 2015b; Rivoli 2013). ${ }^{2}$ Arguably, factory workers at Rana Plaza should never have been confronted with weighing their livelihood against risks to their safety (Bacon 2013; Kazmin et al. 2013). In recent years, numerous global standards have emerged to 'better manage' concerns over worker welfare and opacity in the global supply chain (GSC). Given that the RMG sector has been under considerable scrutiny owing to a range of high profile disasters, the firms operating at Rana Plaza should have been quite familiar with social responsibility processes. Indeed, at the very least, if they believed in the ethos of conducting social audits appropriately, this tragic incident may never have occurred (Foxvog and Gearhart 2013; Montopoli 2013; Nahar and Rahman 2013). The level of commitment of the other stakeholders in the industry is also pertinent to this incident (Elliott 2013; Posner 2013; Yunus 2013). If all the agencies responsible for monitoring firms' responsibility practices were doing their jobs effectively, the firms in this plaza would have been less likely to neglect their responsibilities in relation to worker safety (Kelly 2013; Rights 2014). This is also true for most of the cases of devastating fires ${ }^{3}$ in $\mathrm{RMG}$ supply firms in developing countries.

\footnotetext{
$\overline{2}$ Transparency International provides an idea regarding the overall corruption in this country. According to this organization, Bangladesh's Corruption Perceptions Index score is 26 on a scale of $0-100-$ a failing grade by any measure. 'Corruption translates into human suffering', writes Transparency International, a truth that is tragically evident as the death toll continues to rise in Dhaka.

${ }^{3}$ On 11 September 2012, a devastating fire killed 312 workers of Ali Enterprises-a RMG firm in Karachi, Pakistan. This incident is related to the lack of supply firms' commitment to social responsibility practice. $\mathrm{KiK}$, an international retailer, was the major firm sourcing garments from Ali Enterprise. KiK claimed that it found deficiencies in fire protection in Ali Enterprise in 2007 and fixed this deficiency by 2011. Also, Abdul Aziz, the owner of the factory, claimed that the factory passed an internationally recognized safety test just a few weeks prior to the fire. However, it was revealed that this factory caught fire when a boiler exploded and the flames ignited chemicals that were stored on the floor where staff were working. Almost 400 workers were inside the factory when the blaze erupted; it was found that at the time of this incident all the exit doors in the factory were locked and many of the windows of the factory were covered with iron bars, which made it difficult for workers to escape at the time of the fire and consequently many of the deaths were caused by suffocation. The lack of a standard social responsibility practice was also the main reason for the tragic fire at the Kader Toy Factory in Thailand on 10 May 1993. This incident killed 188 and injured 469 workers, mostly women. It was found that this tragedy occurred primarily because the exit doors of this factory were locked and the stairwell was not well constructed. For details, see Walsh and Greenhouse (2012) and Turner (2012).
}

There is a pressing gap between the objectives and commitments, and practice and outcomes, in social responsibility regulation within the RMG supply chains (Bearnot 2013; Lund-Thomsen and Lindgreen 2014; Nolan 2014; Polaski 2006). As such, this article assesses the social responsibility practices of the supply firms of the RMG industry in developing countries, using the Bangladesh RMG industry as an example. While in theory social responsibility performances may provide a potential instrument for firms (buyers and suppliers) to demonstrate the legitimacy of their operations to stakeholders (Dupire and M'Zali 2016; Perry et al. 2015; Soundararajan and Brown 2014), however, in practice, these performances may be more of a tool for securing competitive advantage and gaining market share. With this in mind, the focus of this article is to present an analysis of how and to what extent a new governance (NG) approach in laws matters to the development of these practices, particularly in the RMG industry within developing countries.

This paper is organized as follows. First it provides an overview of the GSC structure and offers a description of the social responsibilities of global buyers and suppliers within it. Second, it specifically looks at the Bangladesh RMG industry in two steps; firstly examines the overall responsibility practices, and secondly, assesses the social responsibility practices of RMG supply firms. Then it considers the NG approach to law reform and assesses its value to supply firms in developing countries where nonlegal drivers are either inadequate or ineffective. In the fifth part, it describes how the NG approach can be included in laws with the aim of improving firms' social responsibility practices in these countries. Finally, it concludes with the implications for theory and practice, as well as the potential and future research direction. Although this article focuses on Bangladesh, its principles may apply to other developing countries where the social responsibility standards of RMG supply industries are below an acceptable standard.

\section{Social Responsibility in the Global Supply Chain}

The GSC is a quasi-hierarchical relationship between buyers and suppliers, in which the two parties are not joined by ownership, but are engaged in a long-term relationship. This relationship generally includes two types of chains: buyer-driven and supplier-driven chains. Buyerdriven chains are characteristic of labour intensive industries such as the footwear, clothing and toy industries in developing countries (Kaplinsky and Morris 2001; Kaplinsky and Readman 2001; Luetkenhorst 2004). Supplier-driven chains refer to those industries that produce semi-final products such as machineries, petroleum products, electronic parts. It is therefore important that both 
buyers and suppliers engage in procedures that support socially responsible business practices.

Political pressure has made many industries attune to the needs of the environment and society. These developments have altered the way in which some firms attempt to meet social responsibilities. This has resulted in a complex and multidimensional organizational phenomenon that requires stakeholders in the GSC pragmatically maintain social responsibility standards (McBarnet et al. 2007; Vogel 2005). Given this, the following sections of this part succinctly describe social responsibility practices in the GSC framework.

\section{Social Responsibility Practices of Global Buyers in GSC}

When considering which social responsibility practices to include in a business structure, global buying firms are either guided by an absolutist or relativist philosophy (Kolk and Van Tulder 2004). According to the absolutist philosophy, a firm does not differentiate in relation to wages and working standards between home and host countries (Blowfield 2005; Bowie 1988). In contrast, a firm that is guided by a relativist philosophy considers the host country's context and follows local regulations related to wages and working conditions (Brandt 1983). ${ }^{4}$

Global buying firms generally follow the relativist philosophy because it provides a cost advantage and allows firms to claim that they are engaging in ethical standards by simply following the host country's wage and working standards (Donaldson and Dunfee 1994; Hoque and Faruq 2009). In relying on this approach, these firms usually argue that they have no right to interfere with the labour regulations of another country, and are thus respecting the host country's socio-political context. In following this approach, global buying firms can apply both defensive and

\footnotetext{
${ }^{4}$ The core of the relativist philosophy is that a point in a concept is not an absolute truth or a point in a concept cannot claim absolute validity, but it has a relative and subjective value according to differences in perception and consideration (Baghramian and Carter 2016). Two of the main streams of this philosophy are (a) ethical relativism and (b) cultural relativism. Ethical relativism stresses that the moral principles and ethics do not have any absolute validity; they are regarded as applicable in only limited contexts (Velasquez et al. 2016). This paper focuses on 'cultural relativism' that global buyers follows while sourcing from developing countries. This 'relativism' philosophy stresses that an individual person's beliefs and activities should be understood by others in terms of that individual's own culture (Klein 1977; Gonzalez-Padron et al. 2008; Sobczak 2006). In other words, the code of conduct and strategies of a global buyer should be practical and compliant with the culture of the host country (Winstanley et al. 2002). Some scholars argue that the use of this philosophy allows global buyers to undermine the core of CSR and avoid universal moral rules when making ethical judgements in least developed host countries (Logsdon and Wood 2002; Singhapakdi et al. 1994; Smeltzer and Jennings 1998).
}

proactive strategies (Nicholls 2002). A defensive strategy maintains the minimum legal requirements and avoids playing a part in any policy implementation processes in supply firms (Foster and Harney 2005). Proactive strategies involve global buying firms participating in policy implementation processes in supply firms. Firms using defensive strategies focus more on economic benefits, whereas firms using proactive strategies focus on the social and environmental sustainability of the business operations of the supply firm, and do so by considering the impact the firm has on the society in which the firm operates. Global buying firms presently converge these two types of strategies within their overall operations (Foster and Harney 2005). This convergence assists them in managing legitimate threats while maintaining a cost advantage when sourcing from developing countries. The convergence is reflected in the development of a 'self-regulating' culture in the responsibility auditing practices of global buying firms.

At the individual global firm level, self-regulated responsibility is maintained through codes of conduct or through the incorporation of multi-stakeholder initiatives and guidelines prepared by other social or commercial organizations (Mann et al. 2014; Plank et al. 2012). These self-regulatory instruments can address social, environmental and economic issues, and are largely focused on sectors where brand reputation and export orientation are vital (Amaeshi et al. 2008; Rodriguez-Garavito 2005). Codes related to labour issues are usually associated with the footwear, garments, sporting goods, toy and retail sectors, whereas those related to environmental issues are more likely to be used in industries such as oil, chemicals, forestry and mining (O'Rourke 2003; Utting 2005). The world's largest global buying firms have taken the lead in adopting codes, and in doing so, have applied pressure on supply firms to be socially responsible; which has provided buying firms with the ability to claim legitimacy of their operations in host countries (Kaptein 2004; Levis 2006).

While global buying firms may require supply firms follow socially responsible standards set by codes, compliance is verified through social audits. The rise of social auditing is closely related to the development of the corporate social responsibility (CSR) phenomenon that has appeared in the GSC in recent years (Baron 2001; Davis 2005; Dupire and M'Zali 2016). Carroll and Beiler (1975) defined social audits as an attempt to measure, monitor and evaluate the organization's non-financial performance with respect to its social policies and objectives. In a similar way, Owen et al. (2000) defines social auditing as the process by which an organization determines its impacts on society, and then measures and reports this to the wider community. Such auditing is "intended for both internal 
managerial and external responsibility purposes, and is an outgrowth of changing values that have led society to redefine the notion of a firm's social responsibility" (Batra 1996, p 37).

Social audits are conducted by internal or external audit teams and might be undertaken voluntarily, or as a required part of a supply agreement (Gray 2000, 2001). This auditing process should be based on formal standards of social and environmental monitoring and should be relatable to financial auditing processes (Graham and Woods 2006). This is vital, as it maintains the integrity of the audit by removing the auditors' discretion, which in turn reinforces the claim of independence (OECD 2001).

Unfortunately global buying firms tend to only rely on external auditors when the firm faces major threats as a result of media accusations and/or sustained NGO campaigns, for example, in relation to the use of child labour, or any other inappropriate supplier behaviour (Deegan and Islam 2012). The integrity of the process can further be undermined if the firm being audited is the firm responsible for paying the auditors. PricewaterhouseCoopers examined the impact of these situations when it studied the labour standards in China and Korea, and found "significant and seemingly systematic biases" in the methodologies of the auditors, which "question[ed] the company's very ability to conduct monitoring that is truly independent" (O'Rourke 2000, p. 7). The Tazreen Tragedy, yet another recent disaster to strike the Bangladeshi RMG industry, illustrates how global buying firms are having little influence in developing the social responsibility of their supply firms in developing countries.

Tazreen Fashions Ltd (Tazreen) produced ready-made garments and globally supplied them to many well-known retail brands. On 25 November 2012, a tragic fire broke out in the Tazreen factory, located in Dhaka, Bangladesh, which claimed the lives of 112 employees and injured many more (Solaiman 2013). Factory fires, such as this one are sadly all too common in the RMG industry, and result for many reasons, including overcrowded production lines, electrical faults, inappropriate storage of flammable chemicals, faulty fire extinguishers and fire exits being obstructed by inventory (Solaiman 2013). This incident should never have occurred, particularly as Tazreen is a member of the Bangladesh Garments Manufacturers and Exporters Association (BGMEA), and has been a participant in the buyer-driven GSC for more than 12 years. At the time of the tragic incident, Tazreen had a contract for RMG production with Walmart.

If a supply firm is non-compliance with its social responsibilities, the global buying firm can either "cut and run' or engage in a remediation process (Dickson et al. 2009). Prior to the fire, it is believed that Walmart did not follow either option and there are strong indications that there were multiple Walmart suppliers using Tazreen since April 2012, with at least one supplier filling a Walmart contract when the fire broke out (Dickson et al. 2009). Although Walmart conducted an audit of Tazreen's social responsibility practices, and it was noted as being a 'risky factory', the powerful global buying firm ignored the risks and continued its relationship with Tazreen. Evidently, Walmart failed to do its part in developing the social responsibility of the Bangladeshi supply firms within the RMG industry (Chan and Siu 2010). Walmart should have exercised its powerful authority to initiate a remediation process to create a corrective action plan in collaboration with Tazreen, governmental agencies and other stakeholders (Mamic 2005).

It is possible for global buying firms to make an impact upon the CSR of their suppliers, as they set up and control a wide range of activities within the GSC (Perry et al. 2015; Soundararajan and Brown 2014). Profits in this chain are gained from a "unique combination of highvalue research, design, sales, marketing and financial services that allow the global buying firms to act as strategic brokers in linking overseas factories with evolving product niches in the main consumer markets" (Lin 2007, p. 335). Moreover, as opposed to the producerdriven supply chains, buyer-driven supply chains are decentralized, therefore, suppliers situated in different developing countries do not have bargaining leverage over global buying firms (DiCaprio 2013; Egels-Zandén 2013). Global buying firms, along with international brands, control these activities and are able to shape consumer demand through the use of brand names and strategic networks (Jørgensen et al. 2003; Roberts et al. 2006). With this leverage, they aim to purchase high quality products at low prices that are made in socially responsible ways, but do not want to increase production costs. There is therefore no incentive to be a socially responsible and accountable supplier. Lin (2007) defines this as 'policy schizophrenia', which pushes the RMG suppliers to appear to demonstrate socially responsible practices without actually making any changes.

Evidently, it seems that global buying firms are only concerned with the CSR of supplier's when faced with legitimate threats to the firm's reputation and brand image (Egels-Zandén and Hyllman 2006; Frenkel and Kim 2004; Haltsones et al. 2007; Roberts 2003). These fears have lead buying firm to use codes and monitor standards as "a strategy to reduce reputational risks in the market place" (Cowe 2004; Graham and Woods 2006; O'Rourke 2003). Codes of conduct can increase a firm's profitability, defend legitimate threats from media and civil society organizations, reduce costs as a result of a reduced need to switch suppliers, and can increase competitiveness in the marketplace through enhanced relationships with consumers 
(Goyder and Desmond 2000). ${ }^{5}$ Despite these potentially positive outcomes, global buying firms mainly use them as a risk management strategy, instead of being genuinely concerned socially acceptable occupational health and safety practices. The nature of the work appeared to be influenced by whether or not the media was involved in highlighting particular issues (Graham and Woods 2006; The Financial Times 2004). Consequently, global suppliers also need to be encouraged to promote and employ socially responsible procedures.

\section{Social Responsibility Practices of Global RMG Suppliers in GSC}

RMG supply firms in developing countries generally have four major ways to access the global market. Firstly, as producers selling into final markets on an arms-length basis; secondly, as a group of producers; thirdly, as suppliers in GSC where the global buyers coordinate the production networks; and finally, as part of a transnational corporation-driven vertically integrated network. However, most firms access the global market via the GSC.

In buyer-driven GSCs, firms tend to ensure that their suppliers incorporate social issues into their responsibility practices (Perry et al. 2015; Ruwanpura and Wrigley 2011). This ensures long-term profits, positive product branding and high-standard managerial efficiencies (Black 2008; Dickson et al. 2009; Laudal 2010; Yu 2008). A survey found that out of the three most common criteria on which a global buyer selects its suppliers, two are related to the suppliers' performance in managing social responsibilities (Bellesi et al. 2005). In particular, this survey referred to the RMG industry in Bangladesh, and the suppliers' ability to manage the negative impact of their business operations on both societal and environmental platforms (Bellesi et al. 2005). Another survey on global

\footnotetext{
${ }^{5}$ Claiming responsibility from the global buyers for their suppliers' performance in the sourcing countries is problematic. In another sense, it is hard to establish some sort of cause and effect relationship between the buying firms and their suppliers' activities in sourcing countries. It could be easier if a legal duty can be established in this relationship. But to make them morally responsible is always very hard as it is quite irrational to make one answerable for an action that lies beyond one's control. To this end Amaeshi et al. poses some vital questions: '[w]hat if one's psychological and physical conditions do not permit one to give an account of one's actions, who should be accountable for this case?' In response to this, it could be argued that the more powerful in an economic relationship should bear the responsibilities of the weaker party. However, I think that both the global suppliers and supply firms in sourcing countries should be responsible to society given their relative power positions in the market. Nevertheless, these are critical issues and 'raise the fundamental challenges of fatalism and determinism in relation to the concept of 'responsibility". For details, see Amaeshi et al. (2008) and Craig (2000). I have intentionally avoided a discussion on this issue as I considered this beyond the scope of this article.
}

buyers and their demands for social responsibility practices showed that global buyers asked $60 \%$ of supply firms about their safety policies and regulations, $43 \%$ about their environmental policies and $17 \%$ about social issues (Article 2003). This indicates that the majority of buying firms are considering the social responsibility practices of current and potential suppliers.

Although global buying firms have developed different strategies to respond to their social responsibility needs, they are keen on shifting these responsibilities to their suppliers, for whom these then become regulations (Mann et al. 2014; Rondinelli and Berry 2000). Subsequently, suppliers are required to implement socially acceptable measures and have little power to avoid or alter these requirements (Amaeshi et al. 2008; Emmelhainz and Adams 1999). Suppliers must guarantee that they are able to implement these regulations; demonstrating this through carrying out audits on social responsibility processes (Goedhuys and Sleuwaegen 2013; Graafland 2002; Kaptein 2004). Therefore, if a labour intensive firm wants to be a global supplier it must theoretically be efficient in social responsibility performance (Miles and Munilla 2004; Mollenkopf et al. 2010). ${ }^{6}$

In reality, pressure from global buying firms, and their codes of conduct has had little influence on the social responsibility performance of supply firms (Barrientos and Smith 2007; Kim 2013; Locke et al. 2007, 2009; Wells 2007). This has eventuated because codes fail to produce sustained improvements to RMG suppliers in developing countries (Chan and Siu 2010). Locke et al. (2007) assessed Nike's internal rating of 800 supply firms across 51 countries and found that $44 \%$ of the supply firms did not improve their social responsibility performance; in fact, $36 \%$ recorded a decline. GAP, a leader in using codes of conduct in the GSC, has also publicly acknowledged this limitation (Barrientos and Smith 2007). This concerning realization requires a thorough examination about the social responsibility practices that are currently operational in the Bangladesh RMG industry.

\section{Social Responsibility Practices in the Bangladesh RMG Industry}

\section{The Bangladesh RMG Industry}

Bangladesh is the third largest RMG exporter worldwide, accounting for $4.7 \%$ of global apparel export in 2012,

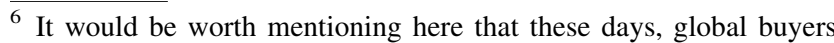
are committing resources to find ways to define and implement this audit system, especially due to the increased environmental and labour related issues and considerable consumer demand for social responsibility among supply firms. For details, see Dickson et al. (2009), Emmelhainz and Adams (1999) and Juulsen and Knudsen (2010).
} 
compared with only $0.6 \%$ in 1990 (World Trade Organization 2013). This industry is divided into two main parts: knitting factories and woven factories. Currently there are more than 6525 factories (Association 2011) employing 4 million workers, of whom $80 \%$ are female (Hossain 2013). Other than a few factories in the exportprocessing zones, almost all are locally owned and situated in the capital city Dhaka, the port city Chittagong or the industrial city Narayanganj. The comparatively low labour costs is the main reason for the expansion of this industry from $0.001 \%$ of the country's total export earnings in 1976 to approximately $77 \%$ by 2011 (ILO 2013)

\section{Social Responsibility Practices in the Bangladesh RMG Industry}

Over the last 15 years, global clothing firms in the United States and Europe have greatly increased their imports from Bangladesh. International fashion brands and retailers, including HandM, CandA, MandS, Walmart, GAP, Levi's, s.Oliver, Tesco, Zara, Target, Carrefour, JCPenney and many more, are not only increasingly relying on the RMG industry in Bangladesh, but they have also set up liaison offices in this country (Brenton and Hoppe 2007; Greenhouse 2013; Rojas 2013). While the main function of these liaison offices is to manage the relationship with the RMG producing firms in Bangladesh, they are also responsible for ensuring that their suppliers enforce workplace regulations that are acceptable to western consumers (Kolk and Van Tulder 2002). Consequently, socially responsible practices and auditing procedures are vital for the RMG industry in Bangladesh. However, the firms currently in operation within this industry do not see these functions as crucial to the benefit of the society within which they operate. Rather, interest lies in social auditing as a means to the maintenance of supply contracts (Egels-Zandén 2013). In the interviews conducted by Islam and Deegan (2008), the interviewees explained that social audits would not be undertaken in the absence of a demand from global buying firms. In this sense, from the perspectives of the local manufacturers and suppliers, social audits are effectively mandatory given that requests for them typically come with every order placed. It is worth noting here that in the above mentioned Islam and Deegan's study, none of the persons interviewed considered the benefits that social audits might create for employees. Indeed, they argued that even the chief officials of supply firms in the industry considered social audits as costly exercises that are only financially beneficial if the outcome of the audit is positive. Such results are generally consistent with the perspectives provided by executives of the
Bangladesh Garments Manufacturer and Exporters Association (BGMEA). Islam and Deegan (2008) also found that the BGMEA undertook particular actions (disclosure of social performance information) because of the expectations of global buyers instead of any underlying ethical reason pertaining to responsibility.

Being less vulnerable to issues of legitimacy and reputation, these supply firms lack the need to implement procedures that are socially responsible (Roberts 2003). As a result, supply firms consciously attempt to decouple social audit policies and practices by engaging in elaborate symbolic actions to deceive their buyers' auditors (EgelsZandén 2013; MacLean and Behnam 2010; Taylor 2011). For instance, an investigation revealed that most of the RMG factories near the capital city of Bangladesh do not use their effluent plants regularly. They have constructed these plants as a requirement for obtaining orders from the high profile buying firms, but only use them when the buyers and governmental agencies are scheduled to conduct inspections. This investigation into the environmental pollution caused by the export-oriented RMG manufacturing firms covered a region containing three villages (Kumkumari, Khagan and Basaet) located next to the Turag river, approximately $35 \mathrm{~km}$ from Dhaka. These three villages alone have 30 export-oriented RMG manufacturing firms of which almost all have effluent plants (Sarker 2011). These firms are occasionally subjected to inspections and pay fines for not using their effluent plants regularly. Despite this, pollution in these villages is continuing to accumulate and thousands of tonnes of toxic liquids wash through the agricultural fields and enter the Turag river every day. The water in the Turag contains only $0.4-0.5 \mathrm{mg} /$ litre of oxygen and is losing its usual volume of flow, and the local villagers are now exposed to a toxic environment.

Evidently, the current social audit process employed within the Bangladesh RMG industry is flawed for two main reasons. First, the management of a firm in this industry can control the whole process by strategically regulating this practice and disseminating only the information it deems appropriate to advance the firm's image, rather than being truly transparent and accountable to society (Adams 2004; Gray 2001; Parker 2002). Secondly, in the absence of a direct threat, management can confine this auditing to operate largely as a management tool (Hess 2009b; Owen et al. 2000, 2001). In the RMG industry, firms are very focused on profit maximization without complying with national or international legal standards. These are the required legal elements of CSR, and through non-compliance, supply firms are failing to abide by basic standards of social responsibility (Carroll 1991; Visser 2008). In addition, the owners of firms are neglecting basic ethical standards by exploiting labour in poor working 
conditions. In this industry, workers are considered as assets, and hence strategies related to workers are solely based on cost-benefit analyses designed to generate quick returns (Hussain 2007; Majumder and Begum 2000). Although there are some firms which do provide basic human rights and acceptable conditions for their workers, it can still be observed that the industry is focused on economic goals over legal and social responsibilities to stakeholders (Campagine 2010).

Under these circumstances, the legal systems in developing countries could play an important role, but it seems that most of these countries' laws relevant to business and CSR do not have an adequate focus or appropriate strategies to demand that corporate self-regulators fulfil their social responsibilities (Ruwanpura and Wrigley 2011; Raj-Reichert 2013). In Bangladesh, the Companies Act 1994, the Bangladesh Labour Law 2006 and the Environmental Conservation Act 1995 are proscriptive, and they do not have substantive provisions to enable the development of firms' self-regulated responsibility systems (Rahim 2013). The Companies Act 1994 does not provide the required focus on social responsibilities of firms or the liabilities of firm owners for this development. This Act does not incorporate necessary strategies that force directors of supply firms to place social responsibility issues at the centre of their internal policies and strategies (Rahim 2012b). Though the Bangladesh Labour Law 2006 provides a long list of labour rights, the implementation strategies mentioned in it are not sufficient to develop a welfare-oriented workplace management system. Its provisions are descriptive, and the punishment measures detailed in it do not seem worthwhile (Rahim 2012b). The Environmental Conservation Act 1995 asserts some modern ideas to curb industrial pollution, though it does not possess the required strategies to implement these ideas. It prescribes penalties for breaches of its provisions, but it does not provide adequate directions to effectively impose them. Its sole dependence on government agencies for its administration is another disadvantage that makes it ineffective (Rahim 2012b). These laws are based on the command and control approach, which does not support the growing separation of law making in a democratic system. Stones (1975) termed this type of legal approach as 'problematic', arguing that it acts only after a problem has occurred, requires significant costs and policing, does not hold the values of the society and focuses more on duties instead of aspirations (Hess 2009a; Stone 1975).

From a developing country perspective, monitoring the internal regulation of firms is difficult, particularly when the government agencies are highly corrupt (Transparency International Bangladesh 2013) and do not have the necessary expertise to assess corporate responsibility (Rahman and Langford 2012, p. 97). ${ }^{7}$ It is also a problem that a large portion of the media is either owned or supported by the owners of polluting industries. Under these circumstances, scholarly evidence and best practice suggests that regulators should use a mix of regulatory agencies and strategies, rather than relying on any single agency and strategy (Gunningham et al. 1998; Hutter 2006; May 2005; Vogel 2010; Winter and May 2001). A NG approach in law can foster this mix effectively: it can combine various agencies to mitigate the drawbacks in public and private regulations and governmental agencies. The following parts of this article discuss more about this approach in law.

\section{The New Governance Approach to Improve Firms' Social Responsibility}

\section{What is the New Governance (NG)?}

NG comes from a conceptual background which examines how corporate decision-making and people-friendly business strategies have begun to converge. It relies on executive fiduciary duties, stakeholder engagement and economic analysis of management incentives. It addresses how firms incorporate stakeholder-friendly business strategies, examines the role of shareholders and board activism in pushing for social responsibility (Rahim 2012a; Soundararajan and Brown 2014). Also it provides quantitative assessments of reporting practices, indices and ratings that link governance with responsibility. ${ }^{8} \mathrm{NG}$ converges the rule-making power of the government and the strength of stakeholders as well as the private ordering system. This convergence would assist in the development of any strategy for improving social responsibility (Rahim and Alam 2013).

There are significant differences between traditional governance and the NG model. The differences are highlighted in an examination of the approach to socio-political and economic issues in developing countries.

\footnotetext{
7 Corruption in this country is prevalent in both the public and private sectors between 2006 and 2008, Bangladesh was considered the most corrupt country in the world; more recently, corruption has been reduced and Bangladesh has now become the world's 12th and 13th most corrupt country in 2010 and 2011, respectively. Other economies at the 13th position are Ecuador, Ethiopia, Guatemala, Iran, Kazakhstan, Mongolia, Mozambique and the Solomon islands. Of 183 economies, Bangladesh ranks 120th on Transparency international's Corruption Perception index 2011. For details, see Transparency International, 'Corruption Perception index' http://cpi. transparency.org/cpi2011/ at 2 December 2011.

${ }^{8}$ For details, see Gill (2008). Regarding fiduciary duty aspect in NG, see Johnson and Millon (2004) and Blair and Stout (2001). For stakeholder aspect see Mitchell (1992). For economic analysis, see Mackenzie (2007), Johnston (2005) and Kolk (2008).
} 


\begin{tabular}{ll}
\hline Dimension & Traditional vs new governance \\
\hline Participation by & $\begin{array}{c}\text { The NG approach mobilizes actors } \\
\text { stakeholders }\end{array}$ \\
& (either on their own initiative or in \\
partnership with the state) rather than & relying on government for solutions to \\
public problems (Salamon 2000) & The NG approach emphasizes the \\
application of tools by stakeholders. It \\
programs \\
avoids a reliance on programs or \\
agencies in which problems of \\
politicization or recruitment exist. It \\
proposes that the division between \\
policy and administration (as assumed \\
by classical theory) is not working \\
(Salamon 2000) \\
The NG approach works with networks \\
and not within a hierarchy. This means \\
system of networks \\
that the public problems are not solved \\
by government; third parties can \\
become private actors and become \\
engaged. They will become allies to \\
the government which will lose some \\
control but gain the benefits of the new \\
approach (Kooiman 1993; Trubek and \\
Trubek 2007; Salamon 2000) \\
The NG approach aims to minimize the \\
debate over public versus private. It \\
suggests working with public and \\
private themes. This will replace \\
competition with collaboration \\
(Salamon 2000) \\
The NG approach decentralizes power \\
by replacing the 'command and \\
control' strategy of administration \\
with 'negotiation and persuasion'. It \\
rejects privatization in the free market \\
and proposes that government is still \\
necessary for the provision of public \\
welfare (Salamon 2000)
\end{tabular}

\section{NG Approach in Law}

NG converges the core of the three dominant theories of regulation: public interest, private interest and regulatory capture. While public interest theory protects the public from market failure, private interest theory regards regulation as a tool for transferring the wealth to the interest group with political power (Chalmers et al. 2012; Stigler 1971; Watts and Zimmerman 1979). Regulatory capture theory assumes that the regulatee captures the regulators and thereby dominates the public interest. The NG model provides a chance for both regulators and regulatees to play a role in the framing regulation in a way that serves all stakeholders in the best possible way (Soundararajan and Brown 2014). For example, regulators attempt to link social values to economic incentives and disincentives; stakeholders influence firms to effectively respond to these values; and regulatees develop internal regulation to respond to this in the most effective manner (Hess 2009a). Rubin (2005) finds NG approach preferable where the regulator "knows the result it is trying to achieve but does not know the means for achieving it, when circumstances are likely to change in ways that the [regulator] cannot predict, or when the [regulator] does not even know the precise result that she desires' (p. 2131).

There may be potential reservations that this approach may facilitate more pronounced government intervention in these autonomous processes by imposing particular predetermined distributive outcomes. However, an NG approach to laws is aimed at empowering the many, rather than emboldening existing power hierarchies, particularly in terms of the role of the state. Thus, NG is a means of creating positive regulation that seeks to devolve and confer the regulatory power of different social actors to ones' self-regulatory processes (Barnard et al. 2005). The laws that allow collective bargaining by trade unions to make qualified exceptions to limits on working time, or similar standards in labour management, could be said to incorporate the NG approach (Barnard et al. 2005). With this approach, a law can try to 'regulate' not only through 'performance' but also through influencing centres of 'reflexion' within other social sub-systems (Wilthagen and Rogowski 2002). It can create a situation where decisions are made on the basis of procedures. This results in decisions being made by the stakeholders whose interests will be directly affected (Fiorino 1999).

If such pluralism is considered vital in any legal regulation, including NG approach in laws is a viable way to incorporate the notion of responsibility into firms' internal management practices. Indeed, embedding NG into legislative processes could help regulators create a more socially responsible regulatory culture, as non-governmental stakeholders would be in a stronger position to persuade firms' management to embrace the ethos of social responsibility (Grabosky 1995). This is particularly necessary for Bangladesh where agencies of the state "have been captured by members of a powerful nexus who have developed a symbiotic relationship with the state, affecting its institutional capacity to reduce corruption, strengthen transparency and accountability" (Alam and Teicher 2012, p 858). A point which is particularly relevant to the RMG industry. The size of the industry means that the government must now respond to the demands of garment factory owners. As a collective group, these owners have now emerged as a 'central political player' (Kazmin 2010). They have the ability to influence both the legislative and executive branches of the state. Their power is such that state agencies promote the interests of the industry, and defer to non-involvement in labour rights and issues by 'watching from the side line' (Haque and Azmat 2015). 
It would be worth mentioning here that the criticism regarding 'hollowing the state' is not a moot point in the context of a NG approach in law. The basis of such law is neither totally 'decentred' or 'centred', nor created only by the state or private parties. ${ }^{9}$ Rather, it is based on the conceptual core of both decentred and centred understandings of law (Scott 2004). While its values are determined by political powers, its implementation strategies are provided by private actors (Rahim 2013). In the context of the pluralisation of actors exercising social power (where it is accepted that government does not have a monopoly on power and governance should not be controlled solely by the private parties) the NG approach disperses legal control. The control is shared between social actors within the broader context of regulators and regulatees (Rahim 2013; Soundararajan and Brown 2014). Here, the rationale behind this dispersal of power is that the greater scope for exercising autonomy will facilitate the regulatees' ability to integrate social values within their governance.

The inclusion of a NG approach in laws is complex, as this approach aims to incorporate interactions between actors, the nature and relevance of which changes over time. Since these interactions are intricate and the actors involved are diverse in their goals, intentions, purposes, norms and abilities, this legal approach might seem overly involved. Nonetheless, it possesses rationality and coherence in its structural formation (Rahim 2013). The following section takes a look at the prospect of a strategy for inserting the NG approach in laws to improve firms' social responsibility.

\section{Using the NG Approach in Laws to Improve Social Responsibility}

In the business regulation landscape, the NG approach to laws links sociological conditions to business regulations, instead of the orthodox cost-benefit analysis or command and control regulations approach. This approach is considered to be a vital part of a regulatory policy that desires to think reflexively about regulation and tend to indirectly regulate the social and individual actions (Black 2002a; Morgan 2003; Baldwin et al. 1998). This legislative approach denotes the presence of a strategy that could initiate a series of activities in which both regulatees and regulators can reach a given objective (Parker 2007). Laws that empower stakeholders to influence policy framing in

\footnotetext{
9 For details of 'hollowing the state' see McCann (1996) and Rosenberg (1992, 2008); regarding the understanding of 'decentred' law, see Black (2002b) and Blackett (2000). For the understanding of 'centred' law, see Teubner (1987) and Nokolas (1999).
}

firms can be an effective incorporation to this $\mathrm{NG}$ approach. It must also be noted that the core of stakeholder thinking enhances the NG approach in law to improve firms' social responsibility. As such, the definition and identification of a stakeholder is important in understanding how this approach works in a legal context (Deegan and Shelly 2006).

Very simply, the word 'stake' means a right to do something in response to any act or attachment (Rahim 2011a). Since rights are generally associated with liabilities, this word also includes liabilities incurred for enjoying a particular right. Hence, a stake could be a reasonable share of something. It could also be a financial involvement with an entity or industry. From the perspective of an organizational stakeholder, Carroll identifies three sources of stakes, with ownership and moral rights at opposite extremes, and interest lying in between the two limits (Siljala 2009, p. 23).

The word 'holder' denotes a person or entity that faces some consequences or needs to respond to an act or to meet a certain need (Rahim 2011a). From the organization and management perspective, Freeman defines a stakeholder as "any group or individual who can affect or is affected by the achievement of the firm's objectives" (Freeman 1984, p. 46).

Carroll and Buchholtz (2009) define 'stakeholders' from a broader perspective, positing that they can be "any individuals or groups who can affect or are affected by the actions, decisions, policies, regulations or goals of an organisation" (p. 113). Mitchell et al. (1997) conversely divides stakeholders into three groups based on the salience of their power, legitimacy and urgency of their claims. Hence employees, customers, owners, competitors, government and civil society organizations could all be stakeholders of a firm. Gray et al. (1996) extended these categories by including future generations and non-human life to this list (Gray et al. 1996; Siljala 2009).

Within business and societal relations, the core ideas ${ }^{10}$ of stakeholder thinking are that:

1. Stakeholders can create standards for firms and reflect on firms' implementation of these standards (Freeman

\footnotetext{
10 These ideas indeed challenge the central position of managerial capitalism. There are two arguments for this challenge. The first argument considers that today's firms are no longer fit for the old modelled governance. It argues that the concept of ownership has shifted, and that firms can no longer accurately be viewed as private property to their owners. The second argument develops around the power relationship between business and society. It claims that social power comes with social responsibility, and hence failing to mitigate the costs that arise out of industrial pollution, hazardous products, job dissatisfaction etc., must raise questions about the exercising and limiting of corporate power.
} 
et al. 2004; Gilbert and Rasche 2008; Hill and Jones 1992; Rahim 2011a), and

2. Firms have a responsibility to consider stakeholders' views in their internal regulation (Evan and Freeman 1988; Jones and Wicks 1999; Kaler 2003; Phillips 2003; Reed 2009).

Consequently, there could be regulatory strategies to use stakeholder engagement to develop firms' responsibility for social issues (Crane et al. 2004). The Proper Prokasih Program of Indonesia is an example of this. Under this program, regulators rank the performance of individual firms using surveys, a pollution database of team reports and independent audits. They also make their findings available to the public (via a colour-coded system of business activities that have environmental impacts). The instruments in this program allow stakeholders to question firms that have non-satisfactory performance standards. Therefore, if a firm is marked as black, blue, or red that firm usually needs to negotiate its pollution-control strategies with stakeholders from public agencies, environmental groups and community representatives. In fact, various countries have already utilized this or similar approaches.

The United States has incorporated this NG approach in both the National Environmental Policy Act 1969 and the Emergency Planning and Community Right-to-Know Act 1986. Under these Acts, the Environmental Protection Agency (EPA) prepares a 'toxic release inventory' and makes it accessible to the public. ${ }^{11}$ This strategy "has dramatically outperformed all other EPA regulations over the last 10 years in terms of overall [toxin] reductions and that it has done so at a fraction of the cost [of]... other programs" (Fung and O'Rourke 2000, p. 116; Fung et al. 2004; Hess 2007). Various Chinese laws also give stakeholders a say in the regulation of policies that control a firm's internal management strategies (Zhao et al. 2013). These laws include the National Consumer Rights Protection Law; the Defective Automobile Products Recall Regulation 2004; the Environment Impact Assessment Law 2002; the Labor Contract Law 2008 and the Labor Dispute Mediation and Arbitration Law 2008.

Similar legislative frameworks were also employed in India and the Netherlands. The relevant Indian examples include the Consumer Protection Act 1986, the Environmental Protection Act 1986 and the Industrial Disputes Act 1980 (Zhao et al. 2013). The examples from the Netherlands include the Structure Act 1971 and the Works

\footnotetext{
11 The Environmental Protection Agency first released its publication in 1980. It published information about the top emitters of toxic chemicals at the national level in national newspapers and the specific figures of the region's largest polluters in the local newspapers. For details, see Snyder (2007).
}

Council Act 1971. These Acts have given a legal right to the employees to monitor a firm's internal policy framing, allowing the non-shareholder stakeholders to address the gap between the firm's self-regulation and public policy goals.

The basis of this stakeholder oriented NG approach is a combination of a few socio-economic principles-a firm's operations need to be legitimate to ensure that they are functional, particularly where stakeholders are the most suitable source in gaining legitimacy. Moreover, since stakeholders can also be the consumers, their collective initiatives have the ability to affect the business performance of a firm (Owen et al. 2001; Unerman et al. 2007; Unerman and Bennett 2004). Although countries do and should employ differing legislative schemes, there are similarities in terms of the theory behind the application of this approach.

Bangladesh can also incorporate this NG approach by reforming legislation to ensure that stakeholders have an input in the social responsibility practices of supply firms within the RMG industry. This is vital because employers in this industry treat their labour force as a fixed cost and do not want to index social responsibility practices to productivity (Khatun 2008). Although these approaches may provide initial benefits, they may lead to frequent labour agitations and a tendency to ignore social responsibility issues in the long term. Islam and Deegan (2008) have illustrated this attitude, describing a notice ${ }^{12}$ circulated to the members of the BGMEA, which stated that firms should not use child labour due to the "potentially negative economic effects of being identified as using child labour, and the impact this had on the survival of the industry" (p. 854).

Currently, the usual corporate attitude towards social responsibility within this industry is as follows: "[W]e are complying with all the rules and regulations, but we do not need to disclose" (Belal 2008, p. 38). This attitude conveys the message of "[t]rust us, and everything will be alright" (Nasrullah and Rahim 2014), however, this corporate outlook has not been reflected in management strategies. A survey-based study conducted by the Centre for Policy Dialogue has revealed a gap between corporate promises and reality in Bangladesh. This study found that more than $60 \%$ of the respondent firms did not have well-articulated policies to deal with worker rights and related issues, and none of the responding firms had a director assigned to address these issues (Jabed and Rahman 2003, p. 5). On the issues of sustainable development and human rights, only 11.1 and $4.4 \%$ of firms respectively, had people dedicated to these issues at a management level (Jabed and Rahman 2003). This article accordingly advocates for the legislative

\footnotetext{
${ }^{12}$ Circular No. BGA/ssd/2005/128, Dec. 10, 2005.
} 
incorporation of 'bounty hunters' and protection for whistle blowers, to add a NG approach to laws that govern the social responsibility performance of the RMG industry in Bangladesh.

\section{Legal Assurance for the 'Bounty Hunters' Rights and Responsibilities}

Bangladesh can introduce a new law to acknowledge the rights and responsibilities of 'bounty hunters' as long as the 'bounty hunters' are assisting the regulators in monitoring corporate fraud and social responsibility within the country (Rahim 2011a). This legal acknowledgement can assist government agencies, the BGMEA and global buying firms to use the skills of different professional groups acting within the industry. Once the law grants the right to intensify this approach, a significant number of professionals (as bounty hunters) would be encouraged to continuously observe the actions of firms' and check irregularities in audits of non-financial issues. An impact of this strategy would be that the firms are more able to meet their legal requirements, social commitments and are less interested in management of government authorities through inappropriate means (Harrison and Wicks 2013; Soundararajan and Brown 2014).

The term 'bounty hunters' refers to individuals or professional bodies who are experts in using secondary materials to discern what the real situation is. For example, private auditors may be able to discover missing information by assessing a firm's social responsibility profiles. They could be considered to be bounty hunters. The incentive for bounty hunters is that they can obtain a share of the results they achieve for the authoritative bodies (for example, global buyers, government and the BGMEA). ${ }^{13}$ Where the social audit reports of firms in the RMG industry are available in a usable form, they can be assessed by private auditors. These individuals might highlight a point which a supply firm auditor or a buying firm affiliated auditor concealed or intentionally overlooked. In this situation, the government, the BGMEA or the consortium of buying firms would not hesitate to provide financial remuneration to the auditor. This would provide further incentive to detect more anomalies or loopholes in the social auditing regulations of supply firms (Harrison and Wicks 2013).

A relevant law would assist in creating potential bounty hunters by providing a direction to the government agencies, industry organizations, business partners and the professional bodies to share their information and expertise for the benefit of the whole industry (Harrison and Wicks

\footnotetext{
13 On the effectiveness of private bounties for detecting corporate wrongdoing, see Fisse and Braithwaite (1983).
}

2013). The factory owners' association within the RMG industry in Bangladesh is well organized and holds a rich set of data on factory information. The buyers' consortium for this industry has developed a database, mostly containing information on issues of social responsibility within Bangladesh. The government also holds significant records on these factories' performances, as this flagship industry is one of the biggest foreign currency earners. There is potential for the BGMEA, and buyers' consortiums, to provide a guideline for accessing such information by the members of some professional bodies. This would assist the increase the number of potential bounty hunters for this industry.

A law on the rights and accountability of the 'bounty hunters' would create roles for members of professional bodies to assist in the regulation of socio-economic issues in the Bangladesh RMG industry. This would also help to develop the credibility of the responsible institutions. Institutions in this industry, for instance, the trade unions are very politicized (Kabeer and Mahmud 2003). Leadership within these organizations is based on political power relationships rather than worker support. A study by Khan (2006) found that only one in seven trade union leaders had experience in the RMG sector. Other trade union leaders came from other organizations and industries through political affiliations. RMG factory owners in Bangladesh often do not support the trade unions, and blame them for disruptive actions which take place in the factories (Kabeer and Mahmud 2003, p. 33). Corruption is also a significant problem, being present in many of the agencies involved in the implementation of regulations (Rahman and Langford 2012, p. 97; Transparency International Bangladesh 2013).

The objective of legally involving 'bounty hunters' in RMG regulation is to increase vigilance in this industry, and to ensure that groups with vested interests do not create information asymmetry and totally control the regulation of responsibility audits. Braithwaite (2011) and Porter (2009) find this to be one of the most effective ways of raising the commitments of all parties to improve the social responsibility performance of firms (Braithwaite 2011; Porter 2009). This regulation strategy has been incorporated into many strong economies. For example, England and Wales incorporated this idea into the Common Informers Act 1951, and in the USA, the Federal False Claims Act 2010, has given the concept a more principled footing (Braithwaite 2006, p. 895). These pieces of legislation detail the incentives for the informer for initiating judicial action against an offender as well as the penalties for abusing the right of private prosecution (Sims 2002). Some developing countries are also including this strategy into their nonlegal regulations. In South Korea, for instance, there is now widespread public education in this area (which is even 
being presented in schools). Recently, Seoul City Council advertised that it would provide a reward of up to US\$1.7 million for information about corruption involving Council staff members (Sang-Hun 2011).

\section{Legal Protection for the 'Whistleblowers'}

Enabling 'whistleblowers' to participate in the regulation of social responsibility could be another useful NG strategy. Pascoe and Rachagan (2005) describe whistleblowing as "the disclosure of information by someone who reasonably believes such information is evidence of contravention of any laws or indicates any mismanagement, corruption or abuse of authority" (p. 106). Any person within an organization can be a whistleblower. In particular, senior managers can be the best whistleblowers, as they understand the positives and negatives of audit strategies and transactions. This means that they are in a better position to publicly announce allegations of fraud or unethical transactions that contravene the law and other social values (Forensic 2005; Miceli et al. 2013; Taylor and Curtis 2010). Furthermore, an aggrieved employee could also become a whistleblower. He or she could 'blow the whistle' by reporting fraud or dishonesty at an organizational level.

By introducing this policy, a firm can indirectly develop a cooperative culture that encourages staff to report misconduct and allows reports to be thoroughly investigated. In addition, proving protection for whistleblowers, it can raise awareness of a firm's code of conduct and initiate ongoing reviews of overall performance (Braithwaite 2013b; Rachagan and Kuppusamy 2013). It can also assist in ensuring that the government, the BGMEA or the buyers' consortium are all adhering to their commitments, which may result in RMG firms becoming more vigilant. This would ultimately facilitate an ethical base in which a firm's policies could be developed to incorporate appropriate social responsibility performances (Rachagan and Kuppusamy 2013).

Whistleblowers may raise an issue to a prescribed body, or other individuals, within the organization. They may also express their allegations to regulators, law enforcement agencies, the media, or other groups concerned with the issue at hand (Latimer 2003; Lindquist 2003).

Although this is not a new approach in regulation, it could be a new and indirect way of improving firms' responsibility in those societies where law enforcement agencies do not have the ability to obtain all the required information. In the United States, if a lawsuit initiated from the information provided by a whistleblower is successful, the whistleblower usually receives $15-25 \%$ of any settlement or judgment resulting from recognition of fraud, unethical transactions or inappropriate policies
(Braithwaite 2006; Hargrove and Raiborn 2013, p. 895). Different legislations in different countries have also incorporated similar incentives and detailed protection of whistleblowers. These legislative frameworks include the Malaysian Anti-Corruption Commission Act 2010; the Capital Market Services Act and Firms (Amendment) Act 2007 of Malaysia; the Public Interest Disclosure Act 1998 of the UK; the Sarbanes-Oxley Act 2002; the Tax Relief and Health Care Act 2006; the Dodd-Frank Wall Street Reform and Consumer Protection Act 2010; the Fraud Enforcement and Recovery Act 2009; and the Federal False Claims Act 2010 of the United States. Australia has also implemented strategies to protect whistleblowers by incorporating provisions into the Australian Corporations Act 2001 (Cth) in 2004 (Pascoe and Welsh 2011).

Effective protection incentives and the acknowledgment of the stakeholder's role in the implementation of legislation could pave the way for a tactical bargaining between stakeholders and firms. If firms commit to reaching the expected performance targets, stakeholders will delay interference with the firms' self-regulation. The crux of this approach is therefore dependent upon the legal power given to stakeholders to intervene with the RMG industry and its responsibility practices. This legal power and protection is particularly necessary for aggrieved workers and for resolving workplace issues before generating industry attention. This would require the development of a new status for RMG workers in Bangladesh.

Traditionally RMG factory workers come from the poorer sections of rural areas (Balch 2013; Kabeer and Mahmud 2003, p. 148). The average salary of a garment worker in Bangladesh is equal to 42, 50 and $33 \%$ of that of India, Nepal and Sri Lanka respectively (Ahmed 2011). In 2006, the average wage per hour in Bangladesh was US $\$ 0.15$ (Chowdhury et al. 2006), which increased to only US $\$ 0.22$ in 2008 (Berik and van der Meulen Rodgers 2008). These uneducated and poor workers are placed in a vulnerable workplace situation and are forced to work in unhygienic environments that violate international labour standards (Berik and van der Meulen Rodgers 2008). These workers usually conceal these workplace issues because of the fear that they may lose their jobs if they report these issues to media or law enforcing authorities. It is normal practice that factory owners follow an informal recruitment system and do not provide contracts for new employees (Kabeer and Mahmud 2003, p. 133). This means that there is a high level of job insecurity (Majumder and Begum 2000), as factory owners are able to dismiss employees at any time. Fearing that they will lose their jobs, workers keep silent on issues of social responsibility (Bansari 2010). Workers are therefore exploited by being offered low, irregular and discriminatory salaries, and are forced to work under conditions that cause medical illnesses (Basak 
2008). Factory owners are powerful enough to obstruct any moves to introduce minimum wages, work-hour restrictions, worker pension schemes or fringe benefits (Ahmed and Peerlings 2009). Moreover, many of these individuals and groups have established factories and manufacturing premises without following building and safety codes (ILO 2013) or appropriate industrial standards (Rashid 2006). This practice has had a significant effect on the local environment and communities and include neighbourhood insecurity, breaches in urban planning codes, increased fire hazards from highly flammable raw material and products, as well as domestic power shortages from the disproportionately high consumption of electricity, gas, air and noise pollutions.

Where a worker has a legal right to raise an issue against a firm's management, there is a greater chance that the RMG industry will become more attentive to maintaining reasonable working conditions. If whistleblowers have the guarantee of job security, they would be more inclined to protect their rights and speak out against the industry's injustices. Whistleblowers and employees can thus assist firms create a forum of restive justice and effectively contribute to this conference.

In Bangladesh, the Company Act 1994 and the Bangladesh Penal Code 1860, could have provisions ensuring rights, immunities and protection of stakeholders. This would encourage both stakeholders and firms to assist law enforcement agencies by providing information about business fraud, mistrust and non-compliance. The success of this initiative is dependent on the available legal protection and incentives. ${ }^{14}$ Laws such as these in Vietnam have helped to create a framework that allowed the community to become organized and to efficiently channel information to regulatory agencies. In turn, this has strengthened the regulatory agencies by reinforcing the notion that firms must not be involved in activities that are harmful to society (Graham and Woods 2006; O'Rourke 2003). Braithwaite defines this approach as a forwardlooking alternative to rule based punitive governance (Braithwaite 2003). He argues that through this stakeholder based NG approach, regulators can persuade firms to "take responsibility for putting things right into the future" (Braithwaite 2013a, p. 462). In the restorative justice conference, "stakeholders in an alleged injustice sit in a

\footnotetext{
${ }^{14}$ It has been reported that the Standing Committee for Law and Justice Affairs of the Parliament of Bangladesh is considering draft legislation, namely, the Public Interest Related Information Disclosure (Protection) Act 2010 that contains whistleblower related provisions. Bangladesh is a party to the United Nations Convention against Corruption, 2007 and the rate of corruption at the corporate level of this country is one of the highest in the world. It is hoped this legislation (if it is passed) would be an important strategy to fight against corruption. For details, see Correspondent (2010).
}

circle to discuss the harm that has been done and arrive at an understanding of its nature, take responsibility for it, and then agree on a set of reforms to prevent recurrence, as well as to repair past harm" (Braithwaite 2013a, p. 462). In a situation where the stakeholders have adequate information and skills to deal with the irresponsible activities of a firm, it is apparent that the firm will have a very limited chance of avoiding responsibility for restoring justice to victims, offenders and communities (Braithwaite 2011).

The Whistle Blowers Protection Act of India was passed in 2011. After the enactment of this legislation, both the central and local governments of this country set up anticorruption whistleblowing hotlines and websites in the last few years to accept information from the whistleblowers (Singh 2014). In India's Tianjin Province, more than $50 \%$ of governmental officials that were prosecuted for abusing public power in 2011 were based on the information provided by whistleblowers (Wendy et al. 2011), while the majority of such cases within the Guizhou Province were based on the information provided by whistleblowers (Wendy et al. 2011). Evidently, India as adopted the ethos of this strategy in the Firm Law 2006 and in the Code of Corporate Governance for Listed Firms in China 2002. Article 5 of the Company Law 2006 states that "a company shall comply with the laws and administrative regulations, social morality and business morality. It shall act in good faith, accept the supervision of the government and the general public, and bear social responsibilities". 15 The Code essentially requires listed firms in China place stakeholder interests at the core of their strategies. Articles 82 and 83 of this Code state that a "listed firm shall actively cooperate with its stakeholders" by providing "the necessary means to ensure the legal rights of the stakeholders". 16 The pressure from global sourcing firms was considered a means to make supply firms more accountable for their non-financial responsibilities. However, as discussed earlier, global sourcing firms are not committed to this kind of strategy and do not have any effective monitoring practices in place to regulate the responsibility practices of their suppliers.

It is also important to note that meeting the demands of stakeholders becomes complicated when there is a powerful nexus of groups with vested interests. As considered by Islam and Deegan (2008), the findings of this article suggest that international buyers drive practices within the RMG industry, not industry owners, RMG workers, the public sector, NGOs, civil society organizations, the local community or the natural environment. This has meant that the needs of some stakeholders have been valued over

\footnotetext{
15 Article 5 of the Firms Law 2006 of China (emphasis added).

16 Article 82 and 83 of the Code of Corporate Governance for Listed Firms in China 2002. For a detailed discussion, see Lin (2007).
} 
others, and garment workers, local communities in proximity to the industry and the natural environment have been systematically neglected. Consequently, it is necessary to identify key stakeholders and address their concerns if the industry is to be sustainable and socially responsible. In particular, employees in the RMG industry, who make up the largest collective stakeholder group as well as creating the product that generates the industry's revenue, have been overlooked and ignored. This is in line with prior research, which has suggested that the RMG industry in Bangladesh is visibly banking on the "vulnerabilities of a highly labour-intensive and poor country as their source of profit" (Rahim 2012b, pp. 105-106). To counteract this, a NG approach in laws can allow for the engagement of all stakeholder groups and other sub-systems by regulating of socio-economic issues within an industry. This approach will be most effective when engagement is used in conjunction with other regulation strategies, rather than as a stand-alone approach. Therefore, the best outcome will be dependent on the ability of different actors and the level of agreement between different modes in social responsibility practices (Kruse 2006). This is vital in transcending the self-interest of firms to achieve the common good (Palazzo and Richter 2005, p. 396).

The core of NG is that it consists of substantive and procedural values derived from a plurality of regulation originating in the state, and it encourages different actors and factors to cooperate in implementing regulation strategies to reach an objective (Karkkainen 2004; Lobel 2004; Salamon 2000). Adopting these NG approach signifies an attempt to create stronger, more nuanced relationships between law and other sub-systems which are underpinned by the autonomous processes of adjustment, representation and participation. Including this approach can channel external pressure, including pressure from local groups, to the firms concerned. Further, this can provide scope to stakeholders to assess firms' internal programs, and can link incentive schemes for the champion and legal sanctions for the laggard (Gunningham 1995; King and Lenox 2000; Rahim 2011b). To this end, political consensus and the involvement of the state are both necessary as they can determine the extent of corporate and stakeholders' rights and liabilities through laws and set public policy goals for industry (Rasche and Esser 2006).

\section{Conclusion}

To guarantee the CSR of the RMG industry in developing counties, this article has argued that a NG approach should be employed to reform the laws related to social responsibility practices of the global suppliers in these countries.
If implemented, this legal approach would ensure that incidents such as the Rana Plaza tragedy do not eventuate.

The key contributions of the NG approach in law are that it empowers a mostly disempowered group of stakeholders in the GSC. Business ethics are held to ransom when an internationally dispersed supply chain is able to operate in developing countries such as Bangladesh where, as argued in this paper, actors such as government (who are purported to act in the public interest) can be susceptible to corruption and endorsing lax standards that are favourable to the concerns of multi-national enterprise. Despite the potential for mechanisms such as social auditing to improve transparency and the discharge of accountability to workers in developing countries, this paper illustrated the shortcomings in these processes and how they were unable to meet their intended purpose. Current forms of regulation in most of the developing countries are unable to address these concerns because the approach in them are mostly 'prescriptive' which limits regulation to a set of activities and do not create enough scopes for non-governmental actors to effectively contribute in regulation. The NG approach to law offers a viable alternative to infuse more ethical responsibility, transparency and accountability in export-oriented industries. It does so by integrating self-regulation and uplifting concern from the grassroots, for example, through whistleblower policies as discussed at the end part of this paper. These will assist in balancing the dominant concerns of global suppliers in developing countries.

The success of integrating NG approach in law accordingly is dependent upon the commitment of global buying firms, political consensus and the involvement of the government. Thus, this integration requires a holistic approach to implementation. The role of the government in such implementation is to set the policy goals of social responsibility practices and to act as a facilitator in achieving these goals with the assistance of other stakeholders. This is particularly relevant for Bangladesh, with its inadequate engagement of public and high corruption prevalence. The need for laws with a NG approach that depends on a combination of different forces, rather than primarily relying on command and control type regulations and market-based rationales, has therefore become apparent.

\section{References}

Adams, C. A. (2004). The ethical, social and environmental reportingperformance portrayal gap. Accounting, Auditing \& Responsibility Journal, 17(5), 731-757.

Ahmed, M. (2011, July 21). Message to Walmart: Low wages hampers the credibility of the top RMG exporting country. The Prothom Alo. 
Ahmed, N., \& Peerlings, J. H. (2009). Addressing workers' rights in the textile and apparel industries: Consequences for the Bangladesh economy. World Development, 37(3), 661-675.

Akhter, S. (2014). Endless misery of nimble fingers: The Rana Plaza disaster. Asian Journal of Women's Studies, 20(1), 137-147.

Alam, Q., \& Teicher, J. (2012). The state of governance in Bangladesh: The capture of state institutions. South Asia: Journal of South Asian Studies, 35(4), 858-884.

Amaeshi, K. M., Osuji, O. K., \& Nnodim, P. (2008). Corporate social responsibility in supply chains of global brands: A boundaryless responsibility? Clarifications, exceptions and implications. Journal of Business Ethics, 81(1), 223-234.

Article. (2003). SMEs and the Supply Chain. Retrieved April 17, 2009, from http://www.article13.com/A13_ContentList. asp? strAction $=$ GetPublication $\&$ PNID $=567$.

Bacon, D. (2013, April 26). Who pays the real price of your shirt? The Progressive.

Baghramian, M., \& Carter, A. (2016). Relativism. Retrieved 11 February, 2016, from http://plato.stanford.edu/entries/relativism/.

Balch, O. (2013, December 5). Breaking the silence on slavery: Why companies need to do more. The Guardian.

Baldwin, R., Scott, C., \& Hood, C. (1998). A reader on regulation. Oxford: Oxford University Press.

Bangladesh Garment Manufacturers and Exporters Association. (BGMEA). (2011). Comparative statement on export of RMG and total export of Bangladesh. Retrieved February 11, 2011, from http://www.bgmea.com.bd/home/pages/TradeInformation.

Bansari, N. (2010). Textile and clothing sector in post MFA regime: A case from Bangladesh, Gender and Trade, Commonwealth Secretariat.

Barnard, C., Deakin, S., \& Hobbs, R. (2005). Reflexive law, corporate social responsibility and the evolution of labour standards: The case of working time. ESRC Centre for Business Research Working Paper No. 294, University of Cambridge, Cambridge.

Baron, D. P. (2001). Private politics, corporate social responsibility, and integrated strategy. Journal of Economics \& Management Strategy, 10(1), 7-45.

Barrientos, S., \& Smith, S. (2007). Do workers benefit from ethical trade? Assessing codes of labour practice in global production systems. Third World Quarterly, 28(4), 713-729.

Basak, B. K. (2008, January 19). Occupational Safety: Factory inspectorate, inspectors and inspection. Daily Star.

Batra, G. (1996). Dynamics of social auditing in corporate enterprises: A study of the Indian corporate sector. Managerial Auditing Journal, 11(2), 36-45.

Bearnot, E. (2013). Bangladesh: A labor paradox. World Policy Journal, 30(3), 88-97.

Belal, A. R. (2008). Corporate social responsibility reporting in developing countries: The case of Bangladesh. Hampshire: Ashgate

Bellesi, F., Lehrer, D., \& Tal, A. (2005). Comparative advantage: The impact of ISO 14001 environmental certification on exports. Environmental Science and Technology, 39(7), 1943-1953.

Berik, G., \& van der Meulen Rodgers, Y. (2008). The debate on labor standards and international trade: Lessons from Cambodia and Bangladesh (No. 2007-03). Working Paper, Department of Economics, University of Utah.

Bhagwati, J. (2014, July 11). Responsibility for sweatshops is local, not global. The Guardian.

Black, J. (2002a). Critical reflections on regulation. Australian Journal of Legal Philosophy, 27(1), 1-27.

Black, J. (2002b). Decentring regulation: Understanding the role of regulation and self regulation in a "post-regulatory" world. Current Legal Problems, 54, 103-146.

Black, J. (2008). Constructing and contesting legitimacy and responsibility in polycentric regulatory regimes. Regulation \& Governance, 2(2), 137-164.
Blackett, A. (2000). Global governance, legal pluralism and the decentered state: A labor law critique of codes of corporate conduct. Indiana Journal of Global Legal Studies, 8, 401.

Blair, M., \& Stout, L. (2001). Director responsibility and the mediating role of the corporate board. Washington University Law Quarterly, 79, 403-448.

Blowfield, M. (2005). Operations and supply chain management going global: How to identify and manage societal expectations in supply chains (and the consequences of failure). Corporate Governance, 5(3), 119-128.

Bowie, N. E. (1988). When in Rome, should you do as the Romans do? Relativism and the moral obligations of multinational corporations. In T. L. Beauchamp \& N. E. Bowie (Eds.), Ethical theory and business. Englewood Cliffs, NJ: Prentice Hall.

Braithwaite, J. (2003). Meta risk management and responsive regulation for tax system integrity. Law \& Policy, 25(1), 1-16.

Braithwaite, J. (2006). Responsive regulation and developing economies. World Development, 34(5), 884-898.

Braithwaite, J. (2011). Essence of responsive regulation. The University of British Columbia Law Review, 44(3), 475-520.

Braithwaite, J. (2013a). Relational republican regulation. Regulation \& Governance, 7(1), 124-144.

Braithwaite, J. (2013b). Flipping markets to virtue with qui tam and restorative justice. Accounting, Organizations and Society, $38(6), 458-468$.

Brandt, R. (1983). Ethical relativism. In T. Donaldson \& P. Werhane (Eds.), Ethical issues in business. Englewood Cliffs, NJ: Prentice Hall.

Brenton, P., \& Hoppe, M. (2007). Clothing and export diversification: Still a route to growth for low-income countries? Washington: World Bank Publications.

Burke, J. (2014, April 19). Rana Plaza: one year on from the Bangladesh factory disaster. The Guardian.

Campagine, C. C. (2010). Bangladesh: Factory workers are entitled to realistic living wage. Retrieved March 7, 2016, from http:// www.fibre2fashion.com/news/apparel-news/newsdetails.aspx? news_id=89200.

Carmody, C. C. (2013). The shirts on our backs: The Rana Plaza disaster, interdependence, and the shifting locus of responsibility. Retrieved March 5, 2016, from 10.2139/ssrn.2292183.

Carroll, A. B. (1991). The pyramid of corporate social responsibility: Toward the moral management of organizational stakeholders. Business Horizons, 34(4), 39-48.

Carroll, A. B., \& Beiler, G. W. (1975). Landmarks in the evolution of the social audit. Academy of Management Journal, 18(3), 589-599.

Carroll, A. B., \& Buchholtz, A. K. (2009). Business and society: Ethics and stakeholder management. Stamford, CT: Cengage Learning.

Chalmers, K., Godfrey, J. M., \& Lynch, B. (2012). Regulatory theory insights into the past, present and future of general purpose water accounting standard setting. Accounting, Auditing \& Responsibility Journal, 25(6), 1001-1024.

Chan, A., \& Siu, K. (2010). Analyzing exploitation: The mechanisms underpinning low wages and excessive overtime in Chinese export factories. Critical Asian Studies, 42(2), 167-190.

Chowdhury, M. A. M., Ali, M. M., \& Rahman, R. (2006). WTO, postMFA era and the Bangladesh RMG sector: An assessment of performance and challenges. South Asian Journal of Management, 13(1), 76.

Claeson, B. S. (2015). Emerging from the tragedies in Bangladesh: A challenge to voluntarism in the global economy. New Solutions: A Journal of Environmental and Occupational Health Policy, 24(4), 495-509.

Correspondent, S. (2010, September 23). Whistleblowers to be protected: Bill placed at parliament. The Daily Star.

Cowe, R. (2004). Risks, returns and responsibility. London: ABI. 
Craig, E. (2000). Prospective and retrospective responsibility. In The Concise Routledge Encyclopedia of Philosophy (p. 768). London: Routledge.

Crane, A., Matten, D., \& Moon, J. (2004). Stakeholders as citizens? Rethinking rights, participation, and democracy. Journal of Business Ethics, 53(1-2), 107-122.

Davis, I. (2005, May 26). The biggest contract. The Economist.

Deegan, C., \& Islam, M. A. (2012). Social audits: Creating real change or simply sustaining 'business as usual'? In AFAANZ 2012 (pp. 1-29).

Deegan, C., \& Shelly, M. (2006). Corporate social responsibilities: Alternative perspectives about the need to legislate. Journal of Business Ethics, 121(4), 499-526.

DiCaprio, A. (2013). The demand side of social protection: Lessons from Cambodia's labor rights experience. World Development, 48, 108-119.

Dickson, M. A., Eckman, M. J., \& Loker, S. (2009). Social responsibility in the global apparel industry. Sydney: Bloomsbury Publishing.

Donaldson, T., \& Dunfee, T. W. (1994). Toward a unified conception of business ethics: Integrative social contracts theory. Academy of Management Review, 19(2), 252-284.

Dupire, M., \& M'Zali, B. (2016). CSR Strategies in response to competitive pressures. Journal of Business Ethics, 116(1), $21-48$.

Egels-Zandén, N. (2013). Revisiting supplier compliance with MNC codes of conduct: Recoupling policy and practice at Chinese toy suppliers. Journal of Business Ethics, 119(1), 59-75.

Egels-Zandén, N., \& Hyllman, P. (2006). Exploring the effects of union-NGO relationships on corporate responsibility: The case of the Swedish clean clothes campaign. Journal of Business Ethics, 64(3), 303-316.

Elliott, K. A. (2013, May 2). Cutting off trade would hurt workers. The Guardian.

Emmelhainz, M. A., \& Adams, R. J. (1999). The apparel industry response to "sweatshop" concerns: A review and analysis of codes of conduct. Journal of Supply Chain Management, 35(3), $51-57$.

Evan, W. M., \& Freeman, E. R. (1988). A stakeholder theory of the modern corporation: Kantian capitalism. In T. L. Beauchamp \& N. E. Bowie (Eds.), Ethical theory and business (pp. 97-105). Englewood Cliffs, NJ: Prentice Hall.

Fisse, B., \& Braithwaite, J. (1983). The impact of publicity on corporate offenders. State University of New York Press: Albany.

Fiorino, D. (1999). Rethinking environmental regulation: Perspectives on law and governance. Harvard Environmental Law Review, 23(2), 441-469.

Fitch, T., Villanueva, G., Quadir, M., \& Alamgir, H. (2015). Prevalence and risk factors for PTSD in injured workers in Bangladesh: A study of surviving workers from the Rana Plaza building collapse. The Lancet Global Health, 3, S33.

Forensic, K. (2005). Integrity Survey 2005-2006. In KPMG LLP US.

Foster, L., \& Harney, A. (2005, April 22). Doctored records on working hours are causing problems for consumer multinationals as they source more of their goods in Asia. Financial Times.

Foxvog, L., \& Gearhart, J. (2013, May 2). Disney's decision to pull out of Bangladesh is a mistake. The Guardian.

Freeman, E. (1984). Strategic management: A stakeholder approach. Boston: Pitman.

Freeman, R. E., Wicks, A. C., \& Parmar, B. (2004). Stakeholder theory and "the corporate objective revisited". Organization Science, 15(3), 364-369.

Frenkel, S. J., \& Kim, S. (2004). Corporate codes of labour practice and employment relations in sports shoe contractor factories in
South Korea. Asia Pacific Journal of Human Resources, 42(1), 6-31.

Fung, A., \& O'Rourke, D. (2000). Reinventing environmental regulation from the grassroots up: Explaining and expanding the success of the toxics release inventory. Environmental Management, 25(2), 115-127.

Fung, A., Weil, D., Graham, M., \& Fagotto, E. (2004). The political economy of transparency: What makes disclosure policies effective? Cambridge, MA: Ash Institute for Democratic Governance and Innovation, John F. Kennedy School of Government, Harvard University.

Gilbert, D. U., \& Rasche, A. (2008). Opportunities and problems of standardized ethics initiatives-A stakeholder theory perspective. Journal of Business Ethics, 82(3), 755-773.

Gill, A. (2008). Corporate governance as social responsibility: A research agenda. Berkeley Journal of International Law, 26, $452-462$.

Goedhuys, M., \& Sleuwaegen, L. (2013). The impact of international standards certification on the performance of firms in less developed countries. World Development, 47, 87-101.

Gomes, W. (2013). Reasons and responsibility: The Rana Plaza collapse. Retrieved March 7, 2016, from https://www.open democracy.net/opensecurity/william-gomes/reason-and-responsi bility-rana-plaza-collapse.

Gonzalez-Padron, T., Hult, G. T. M., \& Calantone, R. (2008). Exploiting innovative opportunities in global purchasing: An assessment of ethical climate and relationship performance. Industrial Marketing Management, 37(1), 69-82.

Goyder, M., \& Desmond, P. (2000). Is ethical sourcing simply a question of good-supply chain management? In R. Thamotheram (Ed.), Visions of ethical sourcing. London: Prentice Hall.

Graafland, J. J. (2002). Sourcing ethics in the textile sector: The case of C\&A. Business Ethics: A European Review, 11(3), 282-294.

Grabosky, P. N. (1995). Using non-governmental resources to Foster regulatory compliance. Governance, 8(4), 527-550.

Graham, D., \& Woods, N. (2006). Making corporate self-regulation effective in developing countries. World Development, 34(5), $868-883$.

Gray, R. (2000). Current developments and trends in social and environmental auditing, reporting and attestation: A review and comment. International Journal of Auditing, 4(3), 247-268.

Gray, R. (2001). Thirty years of social accounting, reporting and auditing: What (if anything) have we learnt? Business Ethics: A European Review, 10(1), 9-15.

Gray, R., Owen, D., \& Carol, A. (1996). Accounting and responsibility: Changes and challenges in corporate social and environmental reporting. London: Prentice Hall.

Greenhouse, S. (2013, July 7). Clothiers act to inspect Bangladeshi factories. The New York Times.

Gunningham, N. (1995). Environment, self-regulation, and the chemical industry: Assessing responsible care. Law \& Policy, 17(1), 57-109.

Gunningham, N., Grabosky, P., \& Sinclair, D. (1998). Smart regulation: Designing environmental policy. Oxford: Oxford University Press.

Haltsones, I., Kourula, A., \& Salmi, A. (2007). Stakeholder pressure and socially responsible purchasing. Finance, Marketing and Production, 3, 47-56.

Haque, M. Z., \& Azmat, F. (2015). Corporate social responsibility, economic globalization and developing countries: A case study of the ready-made garments industry in Bangladesh. Sustainability Accounting, Management and Policy Journal, 6(2), 166-189.

Hargrove, D., \& Raiborn, C. (2013). The problem is fraud: Is the solution government bounties? Business and Society Review, 118(3), 299-324. 
Harrison, J. S., \& Wicks, A. C. (2013). Stakeholder theory, value, and firm performance. Business Ethics Quarterly, 23(01), 97-124.

Hasan, M. (2013, May 15). Hartal, lead time and compliance: The RMG industry in a tight spot. The Financial Express.

Hess, D. (2007). Social reporting and new governance regulation: The prospects of achieving corporate responsibility through transparency. Business Ethics Quarterly, 17(3), 453-476.

Hess, D. (2009a). Regulating corporate social performance: A new look at social accounting, auditing, and reporting. Business Ethics Quarterly, 11(2), 307-330.

Hess, D. (2009b). Social reporting and new governance regulation. Business Ethics Quarterly, 17(3), 453-476.

Hill, C. W., \& Jones, T. M. (1992). Stakeholder-agency theory. Journal of Management Studies, 29(2), 131-154.

Hoque, S. F., \& Faruq, A. A. (2009). Exploitation of labour in Bangladeshi ready-made garment sector. Who is responsible? In $\mathrm{K}$. Fukukawa (Ed.), Corporate social responsibility in Asia. Hoboken, NJ: Taylor and Francis.

Hossain, I. (2013). Rights of women workers in global manufacturing: A study of the garment industry in Bangladesh (pp. 1-257). Milan: University Degli Studi Di Milano.

Hussain, M. G. (2007). Compliance in RMG industry of Bangladesh. In Social compliance and decent work: The Bangladesh perspective. Papers and proceedings of the National Tripartite Meeting on social compliance in the RMG sector (pp. 1-49). Dhaka: International Labour Organization.

Hutter, B. M. (2006). The role of non-state actors in regulation. London: Centre for Analysis of Risk and Regulation.

International Labour Organisation. (2013). Seeking better employment conditions for better socio economic outcomes. Geneva: International Labour Organisation.

Islam, M. A., \& Deegan, C. (2008). Motivations for an organisation within a developing country to report social responsibility information: Evidence from Bangladesh. Accounting, Auditing \& Responsibility Journal, 21(6), 850-874.

Jabed, M., \& Rahman, K. M. (2003). Corporate responsibility in Bangladesh: Where do we stand. Dhaka: The Centre for Policy Dialogue.

Johnson, L., \& Millon, D. (2004). Recalling why corporate officers are fiduciaries. William \& Mary Law Review, 46, 1597.

Johnston, J. S. (2005). Signaling social responsibility: On the law and economics of market incentives for corporate environmental performance. Pennsylvania: University of Pennsylvania Institute for Law and Economic Research.

Jones, T., \& Wicks, A. (1999). Convergent stakeholder theory. Academy of Management Review, 24(2), 206-221.

Jørgensen, H. B., Pruzan-Jørgensen, P. M., Jungk, M., \& Cramer, A. (2003). Strengthening implementation of corporate social responsibility in global supply chains. Washington: World Bank Press.

Juulsen, L. B., \& Knudsen, H. (2010). Communicating CSR in the high street fashion industry. Saarbrücken: Lap Lambert Academic Publishing.

Kabeer, N., \& Mahmud, S. (2003). Globalization, gender and poverty: Bangladeshi women workers in export and local markets. Journal of International Development, 16(1), 93-109.

Kaler, J. (2003). Differentiating stakeholder theories. Journal of Business Ethics, 46(1), 71-83.

Kanzer, A. M. (2013, May 2). Disney's decision to leave Bangladesh was appropriate. The New York Times.

Kaplinsky, R., \& Morris, M. (2001). A manual for value chain research. Retrieved March 7, 2016, from https://www.ids.ac.uk/ ids/global/pdfs/VchNov01.pdf.

Kaplinsky, R., \& Readman, J. (2001). Integrating SMEs in global value chains: Towards partnership for development. Vienna: Unido.
Kaptein, M. (2004). Business codes of multinational firms: What do they say? Journal of Business Ethics, 50(1), 13-31.

Karkkainen, B. (2004). New governance in legal thought and in the world: Some splitting as antidote to overzealous lumping. Minnesota Law Review, 89, 471-497.

Kazmin, A. (2010, October 5). Labour to unlock. Financial Times.

Kazmin, A., Jopson, B., \& Lucas, J. P. L. (2013, April 25). Bangladesh factory disaster highlights regulatory failures. The Financial Times.

Kelly, A. (2013, May 16). Bangladesh's garment workers face exploitation, but is it slavery? The Guardian.

Khan, M. A. (2006, March 1). Garments factories are now death traps. The Daily Star.

Khatun, F. A. (2008). Gender and trade liberalisation in Bangladesh: The case of the readymade garments. Dhaka: Centre for Policy Dialogue.

Kim, J. Y. (2013). The politics of code enforcement and implementation in Vietnam's apparel and footwear factories. World Development, 45, 286-295.

King, A., \& Lenox, M. (2000). Industry self-regulation without sanctions: The chemical industry's responsible care program. Academy of Management Journal, 43(4), 698-716.

Kinley, D., \& Navidi, J. (2013). The long arm of human rights risk: Supply chain management and legal responsibility. The Business and Human Rights Review, 2013(3), 10-14.

Klein, P. A. (1977). The manager and his values: An international perspective by George W. England. Journal of Economic Issues, $11(1), 152-155$.

Kolk, A. (2008). Sustainability, responsibility and corporate governance: Exploring multinationals' reporting practices. Business Strategy and the Environment, 17(1), 1-15.

Kolk, A., \& Van Tulder, R. (2002). The effectiveness of selfregulation: Corporate codes of conduct and child labour. European Management Journal, 20(3), 260-271.

Kolk, A., \& Van Tulder, R. (2004). Ethics in international business: Multinational approaches to child labor. Journal of World Business, 39(1), 49-60.

Kooiman, J. (1993). Modern governance: New government-society interactions. London: Sage.

Kruse, K. (2006). Instituting innocence reform: Wisconsin's new governance experiment. Wisconsin Law Review, 2006, 645-737.

Latimer, P. (2003). Reporting suspicions of money laundering and 'whistleblowing': The legal and other implications for intermediaries and their advisers. Journal of Financial Crime, 10(1), 23-29.

Laudal, T. (2010). An attempt to determine the CSR potential of the international clothing business. Journal of Business Ethics, 96(1), 63-77.

Levis, J. (2006). Adoption of corporate social responsibility codes by multinational companies. Journal of Asian Economics, 17(1), $50-55$.

Lin, L. W. (2007). Corporate social responsibility standards in the global supply chain: Resistance, reconsideration, and resolution in China. Cardozo Journal of International \& Comparative Law, 15(1), 321-370.

Lindquist, S. (2003). Developments in federal whistleblower protection laws. Review of Public Personnel Administration, 23(1), 78-82.

Lobel, O. (2004). The renew deal: The fall of regulation and the rise of governance in contemporary legal thought. Minnesota Law Review, 89(1), 342-470.

Locke, R., Amengual, M., \& Mangla, A. (2009). Virtue out of necessity? Compliance, commitment, and the improvement of labor conditions in global supply chains. Politics \& Society, 37(3), 319-351

Locke, R. M., Qin, F., \& Brause, A. (2007). Does monitoring improve labor standards: Lessons from Nike. Industrial \& Labour Relations Review, 61(1), 1-29. 
Logsdon, J., \& Wood, D. (2002). Business citizenship: From domestic to global level of analysis. Business Ethics Quarterly, 12(2), 155-187.

Luetkenhorst, W. (2004). Corporate social responsibility and the development agenda: The case for actively involving small and medium enterprises. Intereconomics, 39(3), 157-166.

Lund-Thomsen, P., \& Lindgreen, A. (2014). Corporate social responsibility in global value chains: Where are we now and where are we going? Journal of Business Ethics, 123(1), 11-22.

Mackenzie, C. (2007). Boards, incentives and corporate social responsibility: The case for a change of emphasis. Corporate Governance: An International Review, 15(5), 935-943.

MacLean, T. L., \& Behnam, M. (2010). The dangers of decoupling: The relationship between compliance programs, legitimacy perceptions, and institutionalized misconduct. Academy of Management Journal, 53(6), 1499-1520.

Majumder, P. P., \& Begum, A. (2000). The gender impact of growth of export oriented manufacturing in Bangladesh. Dhaka: Bangladesh Institute of Development Studies.

Mamic, I. (2005). Managing global supply chain: The sports footwear, apparel and retail sectors. Journal of Business Ethics, 59(1), 81-100.

Manik, J. A., Greenhouse, S., \& Yardley, J. (2013, April 26). Western firms feel pressure as toll rises in Bangladesh. The New York Times.

Mann, M., Byun, S.-E., Kim, H., \& Hoggle, K. (2014). Assessment of leading apparel specialty retailers' CSR practices as communicated on corporate websites: Problems and opportunities. Journal of Business Ethics, 122(4), 599-622.

May, P. (2005). Compliance motivations: Perspectives of farmers, homebuilders, and marine facilities. Law \& Policy, 27(2), 317-347.

McBarnet, D., Voiculescu, A., \& Campbell, T. (2007). The new corporate responsibility: Corporate social responsibility and the law. Cambridge, MA: Cambridge University Press.

McCann, M. (1996). Causal versus constitutive explanations (or, on the difficulty of being so positive...). Law \& Social Inquiry, 21(2), 457-482.

Miceli, M. P., Near, J. P., \& Dworkin, T. M. (2013). Whistle-blowing in organizations. New York: Psychology Press.

Miles, M. P., \& Munilla, L. S. (2004). The potential impact of social responsibility certification on marketing: A short note. Journal of Business Ethics, 50(1), 1-11.

Mitchell, L. (1992). Theoretical and practical framework for enforcing corporate constituency statutes. Texas Law Review, 70(3), 579-644.

Mitchell, R. K., Agle, B. R., \& Wood, D. J. (1997). Toward a theory of stakeholder identification and salience: Defining the principle of who and what really counts. Academy of Management Review, 22(4), 853-886.

Mollenkopf, D., Stolze, H., Tate, W. L., \& Ueltschy, M. (2010). Green, lean, and global supply chains. International Journal of Physical Distribution \& Logistics Management, 40(2), 14-41.

Montopoli, B. (2013, April 26). Bangladesh factory disaster: How culpable are Western companies? CBS News.

Morgan, B. (2003). The economization of politics: Meta-regulation as a form of nonjudicial legality. Social \& Legal Studies, 12(4), 490-523.

Muhammad, A. (2014, July 25). Post Rana Plaza: A failed system of accountability. The New Age.

Nahar, N. D., \& Rahman, M. S. (2013, May 13). Building collapse: Accountability in question. The Daily Star.

Nasrullah, N. M., \& Rahim, M. M. (2014). CSR in private enterprises in developing countries: Evidences from the ready-made garments industry in Bangladesh. Heidelberg: Springer.
Nicholls, A. J. (2002). Strategic options in fair trade retailing. International Journal of Retail \& Distribution Management, 30(1), 6-17.

Nokolas, R. (1999). Powers of freedom. Cambridge: Cambridge University Press.

Nolan, J. (2014). Refining the rules of the game: The corporate responsibility to respect human rights. Utrecht Journal of International and European Law, 30(78), 7-23.

OECD. (2001). Codes of corporate conduct-An expanded review of their contents. Retrieved March 5, 2016, from http://www.oecd. org/investment/investment-policy/WP-2001_6.pdf.

O'Rourke, D. (2000). Monitoring the monitors: A critique of PricewaterhouseCoopers $(P w C)$ labor monitoring. Retrieved March 7, 2016, from http://www.bollettinoadapt.it/old/files/ document/18107ROURKE_2000.pdf.

O'Rourke, D. (2003). Outsourcing regulation: Analyzing nongovernmental systems of labor standards and monitoring. Policy Studies Journal, 31(1), 1-29.

Owen, D. L., Swift, T. A., Humphrey, C., \& Bowerman, M. (2000). The new social audits: responsibility, managerial capture or the agenda of social champions? European Accounting Review, 9(1), 81-98.

Owen, D. L., Swift, T., \& Hunt, K. (2001). Questioning the role of stakeholder engagement in social and ethical accounting, auditing and reporting. Accounting Forum, 25, 264-282.

Palazzo, G., \& Richter, U. (2005). CSR business as usual? The case of the tobacco industry. Journal of Business Ethics, 61(4), 387-401.

Parker, C. (2002). The open corporation: Effective self-regulation and democracy. Cambridge: Cambridge University Press.

Parker, C. (2007). Meta-regulation: Legal responsibility for corporate social responsibility? In D. McBarnet, A. Voiculescu, \& T. Campbell (Eds.), The new corporate responsibility: Corporate social responsibility and the law. Cambridge: Cambridge University Press.

Pascoe, J., \& Rachagan, S. (2005). Key developments in corporate law reform in Malaysia. Singapore Journal of Legal Studies, 2005, 93-113.

Pascoe, J., \& Welsh, M. (2011). Whistleblowing, ethics and corporate culture: Theory and practice in Australia. Common Law World Review, 40(2), 144-173.

Passariello, C., \& Banjo, S. (2013). Retailers debate reparations for deaths. Wall Street Journal, p. A12.

Perry, P., Wood, S., \& Fernie, J. (2015). Corporate social responsibility in garment sourcing networks: Factory management perspectives on ethical trade in Sri Lanka. Journal of Business Ethics, 130(3), 737-752.

Phillips, R. (2003). Stakeholder theory and organizational ethics. San Francisco: Berrett-Koehler Publishers.

Plank, L., Rossi, A., \& Staritz, C. (2012). Workers and social upgrading in "fast fashion": The case of the apparel industry in Morocco and Romania. Working Paper, Austrian Foundation for Development Research.

Polaski, S. (2006). Combining global and local forces: The case of labor rights in Cambodia. World Development, 34(5), 919-932.

Porter, M. E. (2009). A strategy for health care reform-Toward a valuebased system. New England Journal of Medicine, 361(2), 109-112.

Posner, M. H. (2013, May 2). Address the real challenges. The New York Times.

Rachagan, S., \& Kuppusamy, K. (2013). Encouraging whistle blowing to improve corporate governance? A Malaysian initiative. Journal of Business Ethics, 115(2), 367-382.

Rahim, M. M. (2011a). Meta-regulation approach of law: A potential legal strategy to develop socially responsible business selfregulation in least developed common law countries. Common Law World Review, 40(2), 174-206. 
Rahim, M. M. (2011b). Stakeholder approach to corporate governance and regulation: An assessment. The Macquarie Journal of Business Law, 8, 304-325.

Rahim, M. (2012a). The new governance approach to the devolution of corporate governance. Competition \& Change, 16(4), $343-352$.

Rahim, M. M. (2012b). Legal regulation of corporate social responsibility: Evidence from Bangladesh. Common Law World Review, 41(2), 97-133.

Rahim, M. M. (2013). Legal regulation of corporate social responsibility - A meta-regulation approach of law for raising CSR in a weak economy. Springer

Rahim, M. M., \& Alam, S. (2013). Convergence of corporate social responsibility and corporate governance in weak economies: The case of Bangladesh. Journal of Business Ethics, 121(4), $607-620$.

Rahman, Z., \& Langford, T. (2012). Why labour unions have failed Bangladesh's garment workers. In S. Mosoetsa \& M. Williams (Eds.), Labour in the global south (pp. 87-106). Geneva: International Labour Organization.

Raj-Reichert, G. (2013). Safeguarding labour in distant factories: Health and safety governance in an electronics global production network. Geoforum, 44, 23-31.

Rasche, A., \& Esser, D. E. (2006). From stakeholder management to stakeholder responsibility. Journal of Business Ethics, 65(3), 251-267.

Rashid, M. A. (2006, November). Rise of readymade garments industry in Bangladesh: Entrepreneurial ingenuity or public policy. In Workshop on governance and development, Dhaka (pp. 11-12).

Reed, D. (2009). Stakeholder management theory. Business Ethics Quarterly, 9(3), 453-483.

Reinecke, J., \& Donaghey, J. (2015a). The 'Accord for Fire and Building Safety in Bangladesh' in response to the Rana Plaza disaster. In A. Marx, G. Rayp, L. Beke, \& J. Wouters (Eds.), Global governance of labor rights (pp. 257-277). Cheltenham: Edward Elgar Publishing.

Reinecke, J., \& Donaghey, J. (2015b). After Rana Plaza: Building coalitional power for labour rights between unions and (consumption-based) social movement organisations. Organization, 22(5), 720-740.

Rights, Centre for Business and Human. (2014). Written submission to the U.S. Senate Committee on foreign Relations Hearing: "Prospect for democratic reconciliation and workers' Right in Bangladesh”. New York: New York University Stern School of Business.

Rivoli, P. (2013, May 2). Viewpoint on Bangladesh disaster: It's not all about the West. The Times.

Roberts, S. (2003). Supply chain specific? Understanding the patchy success of ethical sourcing initiatives. Journal of Business Ethics, 44(2-3), 159-170.

Roberts, D., Engardio, P., Bernstein, A., Holmes, S., \& Ji, X. (2006). Secrets, lies, and sweatshops. Business Week, 27, 50-58.

Rodriguez-Garavito, C. A. (2005). Global governance and labor rights: Codes of conduct and anti-sweatshop struggles in global apparel factories in Mexico and Guatemala. Politics \& Society, $33(2), 203-333$.

Rojas, J.P. F. (2013, July 8). 70 International retailers agree to safety inspections at garment factories in Bangladesh. The Independent.

Rondinelli, D. A., \& Berry, M. A. (2000). Environmental citizenship in multinational corporations: Social responsibility and sustainable development. European Management Journal, 18(1), $70-84$.

Rosenberg, G. N. (1992). Hollow hopes and other aspirations: A reply to Feeley and McCann. Law \& Social Inquiry, 17(4), 761-778.
Rosenberg, G. N. (2008). The hollow hope: Can courts bring about social change? Chicago: University of Chicago Press.

Rubin, E. (2005). The myth of accountability and the anti-administrative impulse. Michigan Law Review, 103(8), 2073-2136.

Ruwanpura, K. N., \& Wrigley, N. (2011). The costs of compliance? Views of Sri Lankan apparel manufacturers in times of global economic crisis. Journal of Economic Geography, 11(6), $1031-1049$.

Salamon, L. M. (2000). The new governance and the tools of public action: An introduction. Fordham Urban Law Journal, 28, 1611.

Sang-Hun, C. (2011, September 28). Help wanted: Busybodies with cameras. New York Times.

Sarker, S. (2011, April 20). ETP Plants are inactive, villages and rivers are facing acute industrial pollution. The Prothom Alo.

Scott, C. (2004). Regulation in the age of governance: The rise of the post-regulatory state. In J. Jordana \& D. Levi-Faur (Eds.), The politics of regulation: Institutions and regulatory reforms for the age of governance (pp. 145-174). Cheltenham: Edward Elgar Publishing.

Siljala, E. (2009). Development of corporate social responsibility in Finnish forest industry. Masters Thesis, Lappeenranta University of Technology.

Sims, T. (2002). Corporate returns: Beyond disclosure. Tax Notes, 29, $735-737$.

Singh, A. (2014). Is fraud winning the race against compliance in India? Retrieved February 26, 2016 from http://forensicdiaries blog.ey.com/2014/07/28/is-fraud-winning-the-race-against-compli ance-in-india/.

Singhapakdi, A., Vitell, S. J., \& Leelakulthanit, O. (1994). A crosscultural study of moral philosophies, ethical perceptions and judgements: A comparison of American and Thai marketers. International Marketing Review, 11(6), 65-78.

Smeltzer, L., \& Jennings, M. (1998). Why an international code of business ethics would be good for business. Journal of Business Ethics, 17(1), 57-66.

Snyder, A. M. (2007). Holding multinational corporations accountable: Is non-financial disclosure the answer? Columbia Business Law Review, 2007(1), 565-613.

Sobczak, A. (2006). Are codes of conduct in global supply chains really voluntary? From soft law regulation of labour relations to consumer law. Business Ethics Quarterly, 16(02), 167-184.

Solaiman, S. M. (2013). Unprecedented factory fire of Tazreen fashions in Bangladesh: Revisiting Bangladesh labor laws in light of their equivalents in Australia. Hofstra Labor \& Employment Law Journal, 31, 125.

Soundararajan, V., \& Brown, J. A. (2014). Voluntary governance mechanisms in global supply chains: Beyond CSR to a stakeholder utility perspective. Journal of Business Ethics, doi:10.1007/s10551-014-2418-y.

Stigler, G. J. (1971). The theory of economic regulation. The Bell Journal of Economics and Management Science, 2, 3-21.

Stone, C. D. (1975). Where the law ends: The social control of corporate behavior. New York: Harper \& Row.

Taplin, M. I. (2014). Who is to blame? A re-examination of fast fashion after the 2013 factory disaster in Bangladesh. Critical Perspectives on International Business, 10(2), 72-83.

Taylor, M. (2011). Race you to the bottom... and back again? The uneven development of labour codes of conduct. New Political Economy, 16(4), 445-462.

Taylor, E. Z., \& Curtis, M. B. (2010). An examination of the layers of workplace influences in ethical judgments: Whistleblowing likelihood and perseverance in public accounting. Journal of Business Ethics, 93(1), 21-37.

Teubner, G. (1987). Juridification of social spheres. New York: Walter de Gruyter. 
Than, K. (2013, April 26). Bangladesh building collapse due to shoddy construction. National Geographic News.

The Economist. (2013, May 16) Factory safety: Battle on the brands. The Economist.

The Financial Times. (2004, March 1). Ethical sense: Corporate responsibility means limiting risks. The Financial Times.

Transparency International Bangladesh. (2013). Annual Report 2013. Retrieved March 7, 2016, from https://www.google.com.au/\#q= Transparency+international+Bangladesh +2013 .

Trubek, D. M., \& Trubek, L. G. (2007). New governance \& legal regulation: Complementarity, rivalry, and transformation. Columbia Journal of European Law, 2007(13), 1-26.

Turner, C. (2012, September 22). Pakistan plant certified safe before disaster. Al Jazeera.

Unerman, J., Bebbington, J., \& O’Dwyer, B. (2007). Stakeholder engagement and dialogue. In J. Unerman, J. Bebbington, \& B. O'Dwyer (Eds.), Sustainability accounting and responsibility. London: Routledge.

Unerman, J., \& Bennett, M. (2004). Increased stakeholder dialogue and the internet: Towards greater corporate responsibility or reinforcing capitalist hegemony? Accounting, Organizations and Society, 29(7), 685-707.

Utting, P. (2005). Corporate responsibility and the movement of business. Development in Practice, 15(3-4), 375-388.

Velasquez, M., Andre, C., Shanks, T., \& Meyer, M. J. (2016). Ethical relativism. Retrieved February 11, 2016, from https://www.scu. edu/ethics/ethics-resources/ethical-decision-making/ethical-rela tivism/.

Viedrman, D. (2014, April 4). Supply chains and forced labour after Rana Plaza: Lessons learned. The Guardian.

Visser, W. (2008). Corporate social responsibility in developing countries. In A. Crane, et al. (Eds.), The Oxford handbook of corporate social responsibility (pp. 473-479). Oxford: Oxford University Press.

Vogel, D. (2005). The market for virtue: The potential and limits of corporate social responsibility. Washington: Brookings.
Vogel, D. (2010). The private regulation of global corporate conduct achievements and limitations. Business and Society, 49(1), 68-87.

Walsh, D., \& Greenhouse, S. (2012, December 7). Certified safe, a factory in Karachi still quickly burned. The New York Times.

Watts, R. L., \& Zimmerman, J. L. (1979). The demand for and supply of accounting theories: The market for excuses. Accounting Review, 54(2), 273-305.

Wells, D. (2007). Too weak for the job corporate codes of conduct, non-governmental organizations and the regulation of international labour standards. Global Social Policy, 7(1), 51-74.

Wendy, W., Yu B., \& Charles-Henri B. (2011). Blowing the whistle on corruption in the US and China. Retrieved April 16, 2015, from http://www.corporatecomplianceinsights.com/blowing-thewhistle-on-corruption-in-the-u-s-and-china/ .

Wilthagen, T., \& Rogowski, R. (2002). Legal regulation of transitional labour markets. In I. G. Schmid \& B. Gazier (Eds.), The dynamics of full employment: Social integration through Transitional Labour Markets. Northampton: Edward Elgar.

Winstanley, D., Clark, J., \& Leeson, H. (2002). Approaches to child labour in the supply chain. Business Ethics: A European Review, 11(3), 210-223.

Winter, S. C., \& May, P. J. (2001). Motivation for compliance with environmental regulations. Journal of Policy Analysis and Management, 20(4), 675-698.

World Trade Organisation. (2013). International trade statistics 2013. Washington: World Trade Organization.

$\mathrm{Yu}, \mathrm{X}$. (2008). Impacts of corporate code of conduct on labor standards: A case study of Reebok's athletic footwear supplier factory in China. Journal of Business Ethics, 81(3), 513-529.

Yunus, M. (2013, May 13). After the Savar tragedy, time for an international minimum wage. The Guardian.

Zhao, M., Tan, J., \& Park, S. H. S. (2013). From voids to sophistication: Institutional environment and MNC CSR crisis in emerging markets. Journal of Business Ethics, 122(4), $655-674$. 